\title{
Community Empowerment on the Biopesticide Production from Durian Peel Waste
}

\author{
Ratna Dewi Kusumaningtyas ${ }^{1}$, Ria Wulansarie ${ }^{2}$, Widi Astuti ${ }^{3}$, Nina Hartini ${ }^{4}$, Syarifatur \\ Richana $^{5}$ \\ \{ratnadewi.kusumaningtyas@mail.unnes.ac.id 1 , ria.cheui@gmail.com ${ }^{2}$, \\ widi astuti@mail.unnes.ac.id $\left.{ }^{3},\right\}$ \\ Chemical Engineering Department, Faculty of Engineering, Universitas \\ Negeri Semarang, Indonesia Sekaran Campus, Gunungpati, Semarang, \\ Indonesia 50229
}

\begin{abstract}
Various efforts have been performed to improve the productivity in agricultural sector in Indonesia, such as applying pesticide to kill pests. The use of pesticide shows many drawbacks to the environment. Thus, it is necessary to substitute pesticides with biopesticides derived from natural resources, which is environmental friendly. Among the potential one is biopesticide produced from durian peel waste. Durian peel is the abundant local waste in Gunungpati, Semarang, Indonesia since this area is the durian plantation center. To create the added value on this waste, a community empowerment project was conducted through the production of biopesticide from durian peel. This project increased the community's skill in waste conversion into valuable product, support the waste management, and improve the application of eco-friendly biopesticide.
\end{abstract}

Keywords: Biopesticide, durian peel, community development, waste management, essential oil.

\section{Introduction}

Many efforts have been conducted to enhance the productivity in agricultural sector in Indonesia such as fertilization and applying pesticides. Pesticides are chemicals used for dispatching insects, rodents, fungi, and wild [1]. Several common chemical compounds in pesticides are: 2,4-Dichlorophenoxyacetic Acid (2,4-D), Aldrin/dieldrin, atrazine, chlordane, chlordecone, DDT, DDE, DDD, endosulfan, and endrin aldehyde [2]. The application of pesticides has effectively eradicated unwanted pests. However, chemicals in them can be toxic to non-target species and causes negative impacts to the environment, soil, and human's health [3]. The continuous exposure of pesticides will decrease the plants' productivity and reduce the soil fertility. Their residue on crops can be harmful to the human. Due to the negative effects of synthetic pesticides, the development of biopesticides has paramount importance. Biopesticides are made of natural substance such as animal, plants, bacteria, and minerals. Biopesticides gain an increasing attention because of their environmental friendly characteristic [4]. 
Plant essential oils (Eos) are one of the prospective biopesticides. EOs are discovered in aromatic plants as a mixture of volatile compounds produced as secondary metabolite. EOs can be isolated from plant through extraction process. The main substances in EOs are terpenes, benzene derivatives, hydrocarbons, and others [5]. There are various plants in Indonesia which can yield EOs. Durian (Durio zibethinus L.) is a special plant in Indonesia, and it is a source of EOs [6]. EOs are found in durian peels. Durian peels' EOs contain flavonoid, saponins, and polyphenols that are toxic to pests and mosquitoes and can be utilized as biopesticides [7].

Gunungpati sub-district in Semarang is among the durian plantation centers in Indonesia. During the durian fruit session, the durian peels waste can be found everywhere. There is no specific durian peel management to reduce the negative impact of this waste. To create an added value on it, a community empowerment project related to biopesticides production from durian peel has been conducted in Mangunsari Urban-Village, Gunungpati, Semarang, Indonesia. The work on the synthesis of biopesticides from durian peels using intermediate technology applied to the society has not been conducted previously. Therefore, this project has shown a novelty on the application of intermediate technology to the society on the production of biopesticides from durian peel waste. This community empowerment project has provided these significant contributions to the society and national interest: 1) providing alternatives on the agricultural waste management which involves the community participation; 2) providing knowledge and skill to the society on the production of biopesticides from durian peels using intermediate technology; 3) creating added value on the durian peel waste; 4) providing insight on the economical prospect of the durian peels waste.

\section{Method}

The project was conducted in the 3 steps: 1) production of the durian peel biopesticides in the laboratory; 2) providing the technology to the society; 3) monitoring and evaluation. The first step was production of biopesticide in the laboratory. Initially, durian peel was cleaned and boiled for an hour. Having been boiled, the remaining water was removed and the durian peel was dried for a day under the sun. The next step was cutting and smoothing the durian peels. The smoothed durian peel was then filtered to obtain the liquid extract. The extract was put in a container and mixed with 3 ounces of smooth garlic, $1 \mathrm{~kg}$ salt, and 500 $\mathrm{mL}$ of water. The mixture was stirred until it was homogeneous. It was then fermented in the closed container for 3 days to produce biopesticide.

Table 1. Questionnaire for Pre-Community Service Implementation

\begin{tabular}{|c|c|c|c|c|c|}
\hline \multirow[t]{2}{*}{ No } & \multirow{2}{*}{ Statement } & \multicolumn{4}{|c|}{ Score } \\
\hline & & 1 & 2 & 3 & 4 \\
\hline 1 & I understand the durian peel content & & & & \\
\hline 2 & I understand the benefits of durian peel & & & & \\
\hline 3 & I understand how to manage durian peel waste & & & & \\
\hline 4 & I understand about biopesticides & & & & \\
\hline 5 & I understand that durian peel can be processed into biopesticide & & & & \\
\hline 6 & I understand how to make a biopesticide from durian peel & & & & \\
\hline 7 & I understand the benefits of biopesticides & & & & \\
\hline 8 & I understand the biopesticide entrepreneurial opportunities & & & & \\
\hline
\end{tabular}

Score description: 1 = strongly disagree, 2 = disagree, 3 = agree, 4 = strongly agree 
Table 2. Questionnaire Post Community Service Implementation

\begin{tabular}{|c|c|c|c|c|c|}
\hline \multirow[t]{2}{*}{ No } & \multirow{2}{*}{ Statement } & \multicolumn{4}{|c|}{ Score } \\
\hline & & 1 & 2 & 3 & 4 \\
\hline 1 & I understand the durian peel content & & & & \\
\hline 2 & I understand the benefits of durian peel & & & & \\
\hline 3 & I understand how to manage durian peel waste & & & & \\
\hline 4 & I understand about biopesticides & & & & \\
\hline 5 & I understand that durian peel can be processed into biopesticide & & & & \\
\hline 6 & I understand how to make a biopesticide from durian peel & & & & \\
\hline 7 & I understand the benefits of biopesticides & & & & \\
\hline 8 & I understand the biopesticide entrepreneurial opportunities & & & & \\
\hline 9 & I think community service is useful & & & & \\
\hline 10 & $\begin{array}{l}\text { I think the delivery of material on community service is } \\
\text { interesting }\end{array}$ & & & & \\
\hline 11 & $\begin{array}{l}\text { I think this community service provides knowledge about the } \\
\text { utilization of durian peel }\end{array}$ & & & & \\
\hline 12 & $\begin{array}{l}\text { I look forward to further community empowerment fo the } \\
\text { training of biopesticide-making skills from durian peel }\end{array}$ & & & & \\
\hline 13 & $\begin{array}{l}\text { I expect for the further community development to the } \\
\text { entrepreneurship of biopesticides from durian peel }\end{array}$ & & & & \\
\hline
\end{tabular}

Score description: 1 = strongly disagree, 2 = disagree, 3 = agree, 4 = strongly agree

The second step was implementation in the society. The community service project team from Universitas Negeri Semarang provided knowledge and skills on the biopesticide production from durian peel to the society. The population was the women in Dasa Wisma Group in Mangunsari, Gunungpati, Semarang, Indonesia. The activity included the presentation and the practice of biopesticide production from durian peel. The last step was monitoring and evaluation to know the effectiveness of this project in increasing the community's knowledge and skills. The questionnaires for the pre and post community service implementation are presented in Table 1 and Table 2.

\section{Result and Discussion}

The community development on durian peel biopesticide production was implemented in Mangunsari, Gunungpati, Semarang, Indonesia. Mangunsari has 221.154 ha of land, with a population of 4,038 people [8]. This area is one of durian plantation center in Semarang. This situation contributes the economic benefit from agricultural products trading, but there are also some negative impacts since there will be a huge volume of durian peel garbage during the durian season. Thus far, durian peel waste has not been managed properly and only disposed anywhere, causing the problem to the environment and health. It results in the dirty environment as well as unpleasant odor. The common handling of agricultural waste is by the disposal in landfills, incinerator, or composting for soil. However, incinerator is costly and not environmental friendly. Meanwhile, disposing an abundant solid waste into a landfill requires a very large area [9]. In this work, a novel intermediate technology to convert durian peel into 
biopesticide was implemented to the society. To improve the successfulness of the technology implementation, public involvement was crucial. Community participation was arisen through the community empowerment which provided knowledge and skill to the society.

Prior to implementing the community empowerment program, biopesticide synthesis from durian peel waste was conducted in the laboratory. Durian peels was prospective to be used for biopesticide since it contains high natural flavonoid, saponins, and polyphenols compounds which are toxic to pests [7]. Those compounds were isolated from durian peel by using extraction process. The solvent used was water since it is inexpensive, abundant, nontoxic, and proper for extracting those types of compounds in essential oils [10]. Durian peel extract was formulated with garlic and salt. Garlic was added in the biopesticide formulation since it has shown its capability to control aphid in plant [11], and salt was used to adjust the salinity. The mixture was fermented to ensure homogeneity and enhance the ability in controlling pest.

The next step was community service to present the risk of untreated agricultural waste disposal and to arise the public awareness on the importance of waste management. Next, a training was performed to provide knowledge and skills about the method to produce biopesticide from durian peel extract. The activities involved 11 participants of female gender. The activity has increased the knowledge and skill of the society as well as enhanced the public interest and involvement in agricultural waste management. The participants were enthusiastic and expected for the further program. To determine the effectiveness of this work and to understand the participants' perception, monitoring and evaluation were performed.

Table 3. Results of Questionnaire Recaps for Pre Community Service

\begin{tabular}{|c|c|c|c|c|c|c|c|c|c|}
\hline $\begin{array}{l}\text { Number of } \\
\text { Respondent }\end{array}$ & $\mathrm{X} 1$ & $\mathrm{X} 2$ & $\mathrm{X} 3$ & $\mathrm{X} 4$ & $\mathrm{X} 5$ & $\mathrm{X6}$ & $\mathrm{X} 7$ & $\mathrm{X} 8$ & Amount \\
\hline 1 & 1 & 2 & 1 & 2 & 1 & 1 & 1 & 1 & 10 \\
\hline 2 & 1 & 1 & 1 & 1 & 1 & 1 & 3 & 1 & 10 \\
\hline 3 & 2 & 2 & 2 & 2 & 2 & 2 & 2 & 2 & 16 \\
\hline 4 & 1 & 1 & 1 & 1 & 1 & 1 & 1 & 1 & 8 \\
\hline 5 & 1 & 1 & 1 & 1 & 1 & 1 & 1 & 1 & 8 \\
\hline 6 & 1 & 1 & 1 & 1 & 1 & 1 & 1 & 1 & 8 \\
\hline 7 & 1 & 1 & 1 & 1 & 1 & 1 & 1 & 1 & 8 \\
\hline 8 & 1 & 1 & 1 & 1 & 1 & 1 & 1 & 1 & 8 \\
\hline 9 & 1 & 1 & 1 & 1 & 1 & 1 & 1 & 1 & 8 \\
\hline 10 & 1 & 1 & 1 & 1 & 1 & 1 & 1 & 1 & 8 \\
\hline 11 & 1 & 1 & 1 & 1 & 1 & 1 & 1 & 1 & 8 \\
\hline rxy & 0.94 & 0.79 & 0.94 & 0.79 & 0.94 & $\begin{array}{r}0.9 \\
4 \\
8.5\end{array}$ & 0.55 & 0.94 & \\
\hline $\begin{array}{l}\text { t statistics } \\
\text { t table } \\
(95 \%, 9)\end{array}$ & $\begin{array}{l}8.59 \\
1.83\end{array}$ & 3.95 & 8.59 & 3.95 & 8.59 & 9 & 2.00 & 8.59 & \\
\hline Information & valid & valid & valid & valid & valid & $\begin{array}{l}\text { vali } \\
\text { d }\end{array}$ & $\begin{array}{l}\text { vali } \\
\text { d }\end{array}$ & $\begin{array}{l}\text { vali } \\
\text { d }\end{array}$ & \\
\hline Amount of valid & 8 & & & & & & & & \\
\hline
\end{tabular}


Monitoring and evaluation was conducted quantitatively using a questionnaire to reveal the citizens perception on community service activity. The scores obtained in questionnaire for the pre and post activities were analyzed using T-test. The number of audiences giving the evaluation was 11 persons. The results of the recaps from the questionnaires for pre and post community service implementation are presented in Table 3 and Table 4, respectively. The question/ statement is symbolized by the letter $\mathrm{X}$, in which the $1^{\text {st }}$ statement is symbolized by $\mathrm{X} 1$, and so on.

Table 4. Results of Questionnaire Quotation for Post Community Service Implementation

\begin{tabular}{cccccccccccccc}
\hline Number & $\mathrm{X} 1$ & $\mathrm{X} 2$ & $\mathrm{X} 3$ & $\mathrm{X} 4$ & $\mathrm{X} 5$ & $\mathrm{X} 6$ & $\mathrm{X} 7$ & $\mathrm{X} 8$ & $\mathrm{X} 9$ & $\mathrm{X} 10$ & $\mathrm{X} 11$ & $\mathrm{X} 12$ & $\mathrm{X} 13$ \\
\hline 1 & 1 & 1 & 1 & 3 & 3 & 1 & 3 & 3 & 3 & 3 & 3 & 3 & 3 \\
2 & 3 & 3 & 3 & 3 & 3 & 3 & 3 & 3 & 3 & 3 & 3 & 3 & 3 \\
3 & 3 & 3 & 3 & 3 & 3 & 3 & 3 & 3 & 3 & 3 & 3 & 3 & 3 \\
4 & 3 & 3 & 3 & 3 & 3 & 3 & 3 & 3 & 3 & 3 & 3 & 3 & 3 \\
5 & 4 & 4 & 4 & 4 & 4 & 4 & 4 & 4 & 4 & 4 & 4 & 4 & 4 \\
6 & 3 & 3 & 3 & 3 & 3 & 3 & 3 & 3 & 3 & 3 & 3 & 3 & 3 \\
7 & 3 & 3 & 3 & 3 & 3 & 3 & 3 & 3 & 4 & 3 & 3 & 3 & 3 \\
8 & 4 & 4 & 4 & 4 & 4 & 4 & 4 & 3 & 3 & 3 & 4 & 3 & 3 \\
9 & 3 & 3 & 2 & 3 & 3 & 2 & 3 & 2 & 4 & 4 & 4 & 4 & 4 \\
10 & 3 & 3 & 4 & 4 & 3 & 4 & 4 & 3 & 4 & 4 & 4 & 4 & 4 \\
11 & 3 & 3 & 2 & 3 & 3 & 3 & 2 & 2 & 3 & 3 & 3 & 4 & 4 \\
\hline
\end{tabular}

The construct validity of questionnaire data was conducted by using Pearson's product moment to determine whether the statement on the questionnaire was valid to be used as an instrument to test the effectiveness of community service in the region Mangunsari.

Table 5. Data processing

\begin{tabular}{ccclr}
\hline Respondent & $\begin{array}{c}\text { Before } \\
\text { community } \\
\text { service }\end{array}$ & $\begin{array}{c}\text { after community } \\
\text { service }\end{array}$ & \\
\hline 1 & 10 & 16 & P Value $=$ & Significance $=$ \\
2 & 10 & 24 & $\begin{array}{l}\text { Mean of Before community } \\
\text { service }=\end{array}$ & significant \\
3 & 16 & 24 & Mean of after community & 9,09 \\
4 & 8 & 24 & service $=$ & 24,46 \\
5 & 8 & 32 & Difference $=$ & $-15,36$ \\
6 & 8 & 24 & Tendency $=$ & Enhancement \\
7 & 8 & 24 & & \\
8 & 8 & 31 & & \\
9 & 8 & 21 & & \\
10 & 8 & 28 & & \\
11 & 8 & 21 & & \\
\hline
\end{tabular}


Based on the validity test in Table 5 , it can be concluded that the questionnaire used in community service was valid. The significant impact of the community service on the knowledge improvement of the community about the management and benefits of durian peel waste were also assessed. Therefore, after the implementation of the community service project, the 11 respondents were given questions to determine whether the society was interested in the community service activity. It was found that most audiences were happy and interested in this activity, and they expected for the continuation of this project. On the other hand, the effectiveness of the community service activity was evaluated using paired samples T test by using SPSS Version 23. The hypotheses of this study are as follows:

Ho: Mean score before the implementation of community service $=$ mean score after the implementation of community.

H1: Mean scores before the implementation of community service $\neq$ mean score after the implementation of community service.

Table 6. Results of $\mathrm{T}$ test

\begin{tabular}{lcccccccc}
\hline \multicolumn{10}{c}{ Paired Samples Test } \\
Paired Differences
\end{tabular}

Based on the results of paired samples $\mathrm{T}$ test, Tstatistics $=9.144>$ Ttable $=2.228$. Therefore, the null hypothesis (H0) is rejected and the alternative hypothesis is accepted. In addition, the Sig. value $=0.000<0.005$. It means that there is significant difference in the mean scores before and after the implementation of the community service. Based on the $\mathrm{T}$ test result in Table 5, it can be concluded that community service has a significant influence in terms of increasing knowledge about the management and the benefits of durian peel waste as the feed-stock for biopesticides. The perception of the community can be seen in Table 4. It is shown that, for the statement number $9-13$ on the questionnaire, all the respondents gave the scores of 3-4 (agree and strongly agree). It means that the all participants of the community empowerment were satisfied, enthusiastic, and expecting for the further program.

This community empowerment contributed to increase the community awareness on the negative impact of the untreated waste and improves their participation in waste management. Community involvement in local waste management is urgent since huge amount of waste is generated every day [12] and the local government's capacity to manage waste is overburden. Thus, giving training to enhance the community's skills in waste management will improve the society's involvement in reducing waste generation and disposal. It consequently will increase the quality of their daily life (water, sanitation, health, education, environmental etc.). Creating added value of waste will also provide entrepreneurial opportunity [13, 14]. This project is in line with the national need and can be applied worldwide to solve the similar problem.

\section{Conclusion}

This community service could increase the public awareness on the risk of waste disposal as well as improve their skill about the solid waste management and the intermediate 
technology of producing biopesticide from durian peels. All participants were happy, satisfied, and enthusiastic to enroll the program. This program can increase the public involvement in waste management; thus support the government in improving the daily life quality.

Acknowledgement Financial support from the Faculty of Engineering, Universitas Negeri Semarang for the Community Service Grant 2018 is acknowledged. 


\section{References}

[1] McGrath, G, Suresh, P., Rao, C., Mellander, P-E., Kennedy, I., Rose, M., and van Zwieten, L. : Real-time forecasting of pesticide concentrations in soil. Science of the Total Environment. pp. 709-717 (2019)

[2] Gopalan, N. K. and Chenicherry, S.: Fate and distribution of organochlorine insecticides (OCIs) in Palakkad soil, India. Sustainable Environment Research. pp. 179-185 (2018)

[3] Mubushar, M., Aldosari, F. O., Baig, M. B., Alotaibi, B. M., and Khan, A. Q. : Assessment of farmers on their knowledge regarding pesticide usage and biosafety. Saudi Journal of Biological Sciences. Pp xxx-xxx (xxxx). (in press)

[4] Kumar, S. and Singh, A. : Biopesticides: Present Status and the Future Prospects. J Fertil Pestic. pp. 1-2 (2015)

[5] Mossa, A. T. H. : Green Pesticides: Essential Oils as Biopesticides in Insect-pest Management. Journal of Environmental Science and Technology. pp.354-378 (2016)

[6] Jing-shu, W.U., Chun-yan, W., Zhao-feng., S., Yin., H., Yan-qiong., P., and Feng, Z. : Content determination and Antioxidation Activity of the Total Flavonoids in the Peels of the Jackfriut Artocarpus Heterophyllus and the Durian Durio Zibethinus L. Journal of Fhosan University (Natural Science Edition). pp. 5. (2014)

[7] Hartini, N., Richana, S., Triwibowo, B., Qudus, N., and Kusumaningtyas, R. D. : Sintesis Nanoenkapsulasi Ekstrak Kulit Durian dengan Metode Spray Drying dan Aplikasinya sebagai Biopestisida: Review. Jurnal Teknik Kimia dan Lingkungan. pp 89-95 (2018).

[8] https://patemongunungpati.wordpress.com/2011/06/16/data-kelurahan-se-kecamatangunungpati/, 2011

[9] Boechat, C. L., Arauco, A. M. S., Duda, R. M., de Sena, A. F. S., de Souza, M. E. L., and Brito,

[10] A. C. C. : Solid Waste in Agricultural Soils: An Approach Based on Environmental Principles, Human Health, and Food Security. Ch. 5, pp. 81-102. Intechopen, UK (2017)

[11] Do, Q. D., Angkawijaya, A. E., Nguyen, P. L. T., Huynh, L. H., Soetaredjo, F. E., Ismadji, S., and , Y. H. : Effect of extraction solvent on total phenol content, total flavonoid content, and antioxidant activity of Limnophila aromatic. Journal of Food and Drug Analysis. pp. 296-302 (2014)

[12] Magwenya, T., Svotwa, E., Katsaruware, R.D. Evaluating the efficacy of garlic (Allium sativum) as a bio-pesticide for controlling cotton aphid (Aphis gossypii). Scientia Agriculturae. pp. 54-60 (2016).

[13] Malik, N. K. A., Abdullah, S. H., Manaf, L. A. : Community participation on solid waste segregation through recycling programmes in Putrajaya. Procedia Environmental Sciences. pp. 10-14 (2015)

[14] Andler, S. M. and Goddard, J. M. : Transforming food waste: how immobilized enzymes can valorize waste streams into revenue streams. Science of Food. pp. 1-11 (2018)

[15] Kuckertz, A., Hinderer, S. and Röhm, P., : Entrepreneurship and entrepreneurial opportunities in the food value chain. Science of Food. pp. 1-5 (2019) 